\title{
The Role of Geomorphological Maps in Regional Planning and Management in Indonesia
}

\author{
(Case: Buleleng Regency, Bali)
}

\author{
Dwi Novia Wahyuni ${ }^{1}$, I Nengah Sukarsa ${ }^{2}$, A Sediyo Adi Nugraha ${ }^{3}$ \\ \{dwinoviawahyuni14@gmail.com¹, nengahsukarsa07@gmail.com², adi.nugraha@undiksha.ac.id ${ }^{3}$ \} \\ Universitas Pendidikan Ganesha, Indonesia ${ }^{123}$
}

\begin{abstract}
This research aims to study how much the role of the geomorphological map for planning and managing the territory in Buleleng regency and evaluating the geomorphological map in planning and managing the territory in Buleleng regency. The research was conducted by descriptive and data-collection methods with field surveys and interpretation images Landsat 8 and DEM as primary data. According to this research, planning and managing the regional of Buleleng regency has not fully yet maximized the role of geomorphology map and uses only a few factors between soil types, groundwater, slope, and basin. Then provoke environmental damage by land transfer function and settlements project around the drainage basin. The result of this research is that Landsat 8 and DEM can be used in making geomorphology maps with $81,6 \%$ accuracy of 6 landforms in the Buleleng regency. The geomorphology map role capacity can support reference data until it determines the location at the beginning of construction.
\end{abstract}

Keywords: Landsat 8; Geomorphology Map; Drainage Basin; DEM

\section{Introduction}

The planning and management of the stake are two related and long-term activities. Vast implementation of space planning is a generic term for all systems. Planning is the first stage of development so that the proposed planning should be implemented and applicable [1]. The regional planning and management will doubtless be connected with morphological conditions, the varying cases of either damage such as disaster or land-use change [2][3]. Due to anthropogenic activities, the earth's surface is being significantly altered, and man's presence on the earth profoundly affects the natural environment [4][5]. Buleleng regency with hill morphology and narrow alluvial plains, resulting in land indicated to a limited settlement. 10,60 million population growth in 3 years, it shows an increase of population in Buleleng regency and affects increasing demand for space [6]. The land uses refers to spatial planning that will create environmental sustainability [7] and be a bench point in measuring success in space planning [8]. Besides that, geomorphology planning can be used for a detect disaster such as; erosion and controlling environmental impact from industrial [9].

The forum of Bali Drainage Basin notes that the environmental damage in Bali is 
increasingly severe due to the development of housing around the drainage basin, the industry around the river, and $\mathrm{C}$ digging activity [10]. This environmental problem also caused by human behaviour [11] that would have an impact on residential communities built directly across rivers. The problem of disaster is one of the results of development that pays no attention to the proper location for the building and ignores sustainable development principles. Thus, efforts to reduce potential disasters needed the geomorphological map to support the development of the region [12]. It contained the information needed in planning and managing regions in Indonesia: geology, hydrologic, and the slope of a region.

Based on the background that has been outlined. This research aims to know how far the role of the geomorphological map for planning and management in the Indonesia region, especially in the Buleleng regency. Furthermore, to evaluate the geomorphological map in planning and managing the housing in Bulelengregency.

\section{Methodology}

Buleleng is part of the administrative regency of Bali province. Located between latitudes $8^{\circ} 03^{\prime} 40^{\prime \prime}-8^{\circ} 23^{\prime} 00^{\prime \prime} \mathrm{S}$ and between longitudes $114^{\circ} 25^{\prime} 55^{\prime \prime}-115^{\circ} 27^{\prime} 28^{\prime \prime}$ E. Buleleng regency has a unique topography, where the south side is a hill region, and the north side is the lowland. The settlement growth rate in Buleleng has an increase from 2000 until 2016, about $42,74 \%$ [13]. The research uses the image of Landsat 8 Operational Land Imager/Thermal Infrared Sensor (OLI/TIRS) in 2019 path 161 and 162. DEM Data is a free procured list on the official website of the USGS. The interpretation method refers to the terms of Lillesand and Kiefer by using the interpretation key. The key to interpretation is used, such as; Hue/colour, shapes, textures, patterns, and sites. The interpretation employed is by an overlay of images with DEM data to provide a realistic topographic impression in the field [14]. One display image of remote sensing but regular composites (321), pseudo composites (567), and durability of image spectral imaging reinforce the image coupled with 15 meters resolution of Landsat.

Table 1. The Units of Geomorphological Landform Map

\begin{tabular}{|c|c|c|c|c|c|}
\hline $\begin{array}{c}\text { Type of } \\
\text { landform }\end{array}$ & Code & Annotation & $\begin{array}{r}\text { Type of } \\
\text { landform }\end{array}$ & Code & Annotation \\
\hline $\begin{array}{l}\text { The } \\
\text { denudation } \\
\text { al } \\
\text { landform } \\
\text { (D) }\end{array}$ & $\begin{array}{l}\text { D1 } \\
\text { D2 } \\
\text { D3 } \\
\text { D4 } \\
\text { D5 } \\
\text { D6 } \\
\text { D7 } \\
\text { D8 } \\
\text { D9 }\end{array}$ & $\begin{array}{l}\text { The hills scrape } \\
\text { Mountains eroded } \\
\text { Leftover hill } \\
\text { Isolated hills } \\
\text { Plain barely } \\
\text { Plain barely rises } \\
\text { Slope } \\
\text { Areas with a mass } \\
\text { movement of the rock } \\
\text { Degraded land }\end{array}$ & $\begin{array}{l}\text { The } \\
\text { marine } \\
\text { landform } \\
(\mathrm{M})\end{array}$ & $\begin{array}{l}\text { M1 } \\
\text { M2 } \\
\text { M3 } \\
\text { M4 } \\
\text { M5 } \\
\text { M6 } \\
\\
\text { M7 } \\
\text { M8 } \\
\text { M9 }\end{array}$ & $\begin{array}{l}\text { Beach } \\
\text { Tombolo } \\
\text { Beach ridge } \\
\text { Beach dune } \\
\text { Low tide line } \\
\text { The coastal } \\
\text { alluvial plain } \\
\text { The inundated } \\
\text { coastal } \\
\text { Alluvial plain } \\
\text { Coral reef } \\
\text { Shoal }\end{array}$ \\
\hline
\end{tabular}




\begin{tabular}{|c|c|c|c|c|c|}
\hline \multirow{10}{*}{$\begin{array}{l}\text { The } \\
\text { volca } \\
\text { nic } \\
\text { landf } \\
\text { orm } \\
\text { (V) }\end{array}$} & V1 & Volcanic cone & \multirow{10}{*}{$\begin{array}{l}\text { Karst } \\
\text { landform } \\
(\mathrm{K})\end{array}$} & $\mathrm{K} 1$ & Karst plateau \\
\hline & $\mathrm{V} 2$ & Volcanic slope & & $\mathrm{K} 2$ & Slope and karst \\
\hline & V3 & The foot of the volcano & & & hills eroded \\
\hline & V4 & Flavio volcanic plain & & K3 & Karst \\
\hline & V5 & Lava land & & K4 & topography \\
\hline & V6 & Lahar land & & K5 & Karst alluvial \\
\hline & V7 & Mountainous plains & & & plain \\
\hline & V8 & Denudation volcano hills & & & Dry valleys and \\
\hline & V9 & Boka, dike & & & karst canyons \\
\hline & $\mathrm{V} 10$ & Parasite cone & & & \\
\hline \multirow{15}{*}{$\begin{array}{l}\text { The } \\
\text { structu } \\
\text { ral } \\
\text { landfor } \\
\mathrm{m}(\mathrm{S})\end{array}$} & S1 & Fault block & \multirow{15}{*}{$\begin{array}{l}\text { Fluvial } \\
\text { landform } \\
\text { (F) }\end{array}$} & F1 & Fluvial plain \\
\hline & $\mathrm{S} 2$ & Escarpment fault & & F2 & Riverbed \\
\hline & S3 & Big Escarpment & & F3 & Lake \\
\hline & S4 & Anticlinal mountains & & F4 & Swamp \\
\hline & S5 & Anticlinal hills & & F5 & Rear swamp \\
\hline & S6 & Synclinal mountains & & F6 & Dead river \\
\hline & S7 & Synclinal hills & & F7 & Floodplain \\
\hline & S8 & Monoclinal mountains & & F8 & Dikes \\
\hline & S9 & Monoclinal hills & & F9 & Fluvial spout \\
\hline & $\mathrm{S} 10$ & Dome mountains & & F10 & Alluvial fan \\
\hline & S11 & Dome plain & & F11 & Delta \\
\hline & $\mathrm{S} 12$ & Highland/plateau & & F12 & Delta spout \\
\hline & $\mathrm{S} 13$ & Synclinal valley & & F13 & Delta coast \\
\hline & S14 & Horst & & & \\
\hline & S15 & Graben & & & \\
\hline
\end{tabular}

Source: [15]

Restrictions and the naming of the interpretation results refer to Suharsono [15]. An interpretation is that it is untenable for different landforms (Table 1) and each landform's characteristics. The giving of geomorphological map code was divided into two kinds of $1: 250.000$ and 1:50.000. The scale significantly affects the durability it will display.

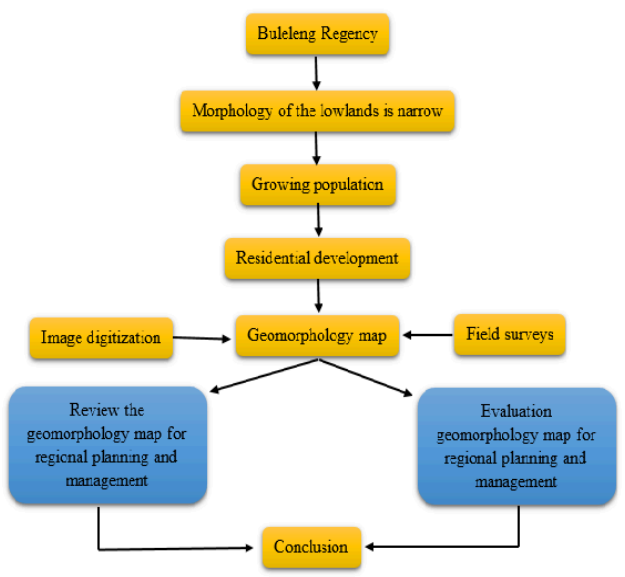

Fig 1. Flowchart Research 


\section{Result and Discussion}

\section{Analysis Geomorphology Map in Regional Planning}

An interpretation of the Landsat 8 image shown on a false composite line at RGB 5.6.7 that features topographic cranking, were using that channel, the ridge of the hills and flows is visible. Image interpretation is used in research provides necessary information such as geology and topographic [16], for regarding their formation to be more accurate, it will require a DEM image to obtain marbles and field surveys. Similar studies have been done [17] to identify formation in Kulonprogo and Wonosari by looking at textures and colours.

Geomorphology identification through Landsat image gained six concepts: denudational landform, volcanic landform, structural landform, fluvial landform, marine landform, and karst landform. Each landform has characteristics and effects on the soil performed mainly for topographical conditions. In the case of disasters that occurred at several points in the Buleleng regency, flooding up to $1.75 \mathrm{~m}$ around Singaraja city, in Jalak Putih residential area, also occurred in Musi village, Gerokgak subdistrict (Figure 2.a.) causes high rainfall intensity, and the primary cause is that housing was located in a fluvial landform were before the construction was a drainage basin. The river that crosses Musi village is seasonal and often dry so that the people of Musi village built settlements around the drainage basin without worrying about flooding. The problems of disaster in the residential areas are a clear example of the potential dangers of building settlements that ignore geomorphology conditions. Figure 2.b. shown a new housing project under construction, but the location was not very suitable for settlement when viewed from the geomorphological map, the risk of landslides as they are built in regions of the denudational landform and located between the dredged hill.

In the past cases and signs of the problem, it is well known that the development of settlement in the Buleleng regency is not entirely because of the condition of the landform. Here the role of a geomorphological map can be a basis for housing development. However, evaluating the geomorphological map's role cannot be a single data to plan the exact location. Only the introductory of information needs to be compared to other data not contained on the geomorphological map to building sustainable development principles.

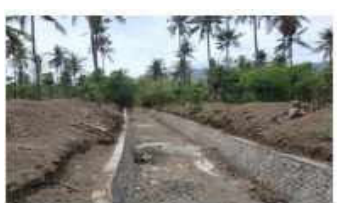

(a)

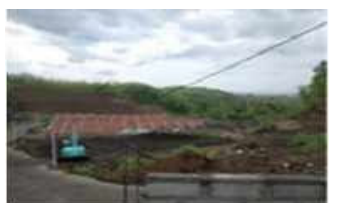

(b)

Fig 2. Settlements development in Anturan Village

\section{Validation Result}

The field survey was carried out at various landform points that are Bubunan as a region with denudational landform, Pulaki Hill to check of structural hills, Gondol Coast to prove the presence of outlying hills and check the organic and marine landform. The landform characteristic table is shown in Table 2. Observations on several landforms in Buleleng regency as follows. 


\section{Denudational landform}

The characteristic of landform founded from the field survey indicated that in the Bubunan region is a denudational hill landform, as shown in Figure 3. (a) the shape of the terraced hills due to high erosion processes, (b) there is a stream below the hill that shows surface water good condition and (c) that shows the dominant soil's texture of sand and clay.

\section{Structural landform}

Based on field survey results, researchers obtained the features of structural hill landform among these are different types of Breksi rock and erosion. Structural hills are evidenced by the type of Breksi rock that the foothold can be seen in Figure 3(d). Structural hills also endure erosion, while Figure 3(e).

\section{Marine Landform}

The field survey for landform was done on the Gondol coast, Gerokgak. The coast has white sand in contrast with the black sand. The leftover hill on the Gondol coast was carrying eroded stone material on the coast. Figure 3(f) shows the coast on which tides occur with white sand from coral runoff and black sand from the erosion of Breksi rock, Figure 3(g) shows the Breksi rock on the beach of the remnant for the hill next to the Gondol coast.

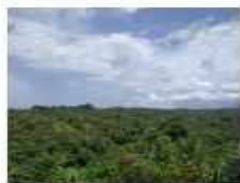

(a)

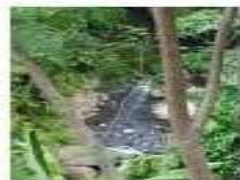

(b)

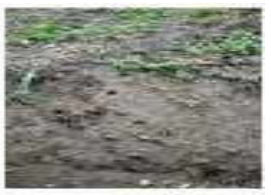

(c)

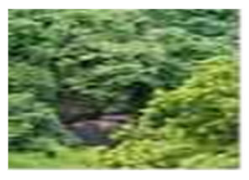

(d)

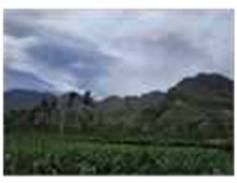

(e)

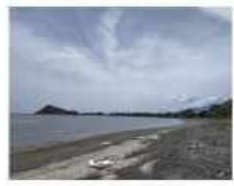

(f)

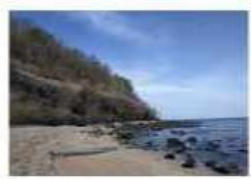

(g)

Fig 3. Landform (a), (b), (c) Denudational, (d), (e) Structural, and (f), (g) Marine.

Table 2. The characteristics of the landscape

\begin{tabular}{|c|c|c|c|c|c|c|c|}
\hline \multicolumn{2}{|c|}{ Terrain unit } & \multicolumn{6}{|c|}{ The characteristics of the terrain and water quality } \\
\hline $\begin{array}{l}\text { Co } \\
\text { de }\end{array}$ & Name & $\begin{array}{c}\text { Relief/ } \\
\text { Morpholog } \\
\mathbf{y}\end{array}$ & Process & Rock types & Soil & $\begin{array}{c}\text { Water } \\
\text { conditio } \\
\text { ns }\end{array}$ & Vegetation \\
\hline $\mathrm{D}$ & $\begin{array}{c}\text { Denudati } \\
\text { onal }\end{array}$ & $\begin{array}{l}40-50^{\circ} \\
\text { A little } \\
\text { bumpy }\end{array}$ & $\begin{array}{l}\text { Eroded } \\
\text { evidenced by } \\
\text { the terraced } \\
\text { hill }\end{array}$ & $\begin{array}{l}\text { Tuff; } \\
\text { Volcanic } \\
\text { mudflow; } \\
\text { Conglomerat } \\
\text { e }\end{array}$ & $\begin{array}{l}\text { Sand; Clay; } \\
\text { Andosol }\end{array}$ & Medium & $\begin{array}{l}\text { Coconut palm } \\
\text { with high } \\
\text { vegetation } \\
\text { density }\end{array}$ \\
\hline $\mathrm{S}$ & $\begin{array}{c}\text { Structura } \\
1\end{array}$ & $\begin{array}{l}27-39^{\circ} \\
\text { Mountain } \\
\text { ridge }\end{array}$ & Denudational & $\begin{array}{l}\text { Breccia; } \\
\text { Tuff; } \\
\text { Conglomerat } \\
\text { e; } \\
\text { Silt rock; } \\
\text { Sandstone; }\end{array}$ & $\begin{array}{l}\text { Gravel on } \\
\text { top; } \\
\text { Sand and } \\
\text { clay on the } \\
\text { base }\end{array}$ & A little & Scrub \\
\hline M & Marine & & $\begin{array}{l}\text { Thinning of } \\
\text { rock into sand }\end{array}$ & $\begin{array}{l}\text { Sandstone; } \\
\text { Coastal }\end{array}$ & $\begin{array}{l}\text { Sand; } \\
\text { Alluvial; }\end{array}$ & Big & $\begin{array}{l}\text { Coconut } \\
\text { palm; }\end{array}$ \\
\hline
\end{tabular}




\begin{tabular}{|c|c|c|c|c|c|c|c|}
\hline & & & & $\begin{array}{l}\text { alluvial } \\
\text { sediment }\end{array}$ & Hidromart & & $\begin{array}{l}\text { Mixed } \\
\text { gardens }\end{array}$ \\
\hline K & Karst & $\begin{array}{l}<45^{\circ} \\
\text { Low hills }\end{array}$ & $\begin{array}{l}\text { Removal of } \\
\text { the seabed }\end{array}$ & Lime & $\begin{array}{l}\text { Gravel; } \\
\text { Clay with } \\
\text { sand }\end{array}$ & $\begin{array}{l}\text { Very } \\
\text { little }\end{array}$ & $\begin{array}{l}\text { Hard trunked } \\
\text { tree; } \\
\text { Thron bush }\end{array}$ \\
\hline $\mathrm{F}$ & Fluvial & $\begin{array}{l}0-15^{\circ} \\
\text { Slope } \\
\text { slightly }\end{array}$ & $\begin{array}{l}\text { Fluvial } \\
\text { sediment, } \\
\text { beach, and } \\
\text { lake }\end{array}$ & Gravel & $\begin{array}{l}\text { Clay; Silt; } \\
\text { Gravel }\end{array}$ & Big & $\begin{array}{l}\text { Vineyard; } \\
\text { Scrub High } \\
\text { vegetation } \\
\text { Density }\end{array}$ \\
\hline V & Volcano & $\begin{array}{l}35-50^{\circ} \\
\text { Belongs to } \\
\text { Beratan } \\
\text { Purba } \\
\text { mountain }\end{array}$ & Volcano & $\begin{array}{l}\text { Breccia; } \\
\text { Lava; Tuff }\end{array}$ & $\begin{array}{l}\text { Clay; } \\
\text { Latosol }\end{array}$ & Less & $\begin{array}{l}\text { High } \\
\text { vegetation } \\
\text { density with a } \\
\text { high variation } \\
\text { of vegetation }\end{array}$ \\
\hline
\end{tabular}

Source: Data processing, 2020.

\section{Remote Sensing Data of Landsat 8 OLI and DEM for Geomorphology Map}

Landform mapping using remote sensing imagery in Indonesia mostly involves visual interpretation techniques to obtain landform features instead of digitally manually. Similar research has been conducted in mapping geomorphology of the Pench reserve area, Chindwara district, India [18]. To improve RGB composite image quality on Landsat 8 in the information of texture from different rock uses $6 / 4 ; 6 / 2 ; 7 / 6$ channels and pan-sharpened method.

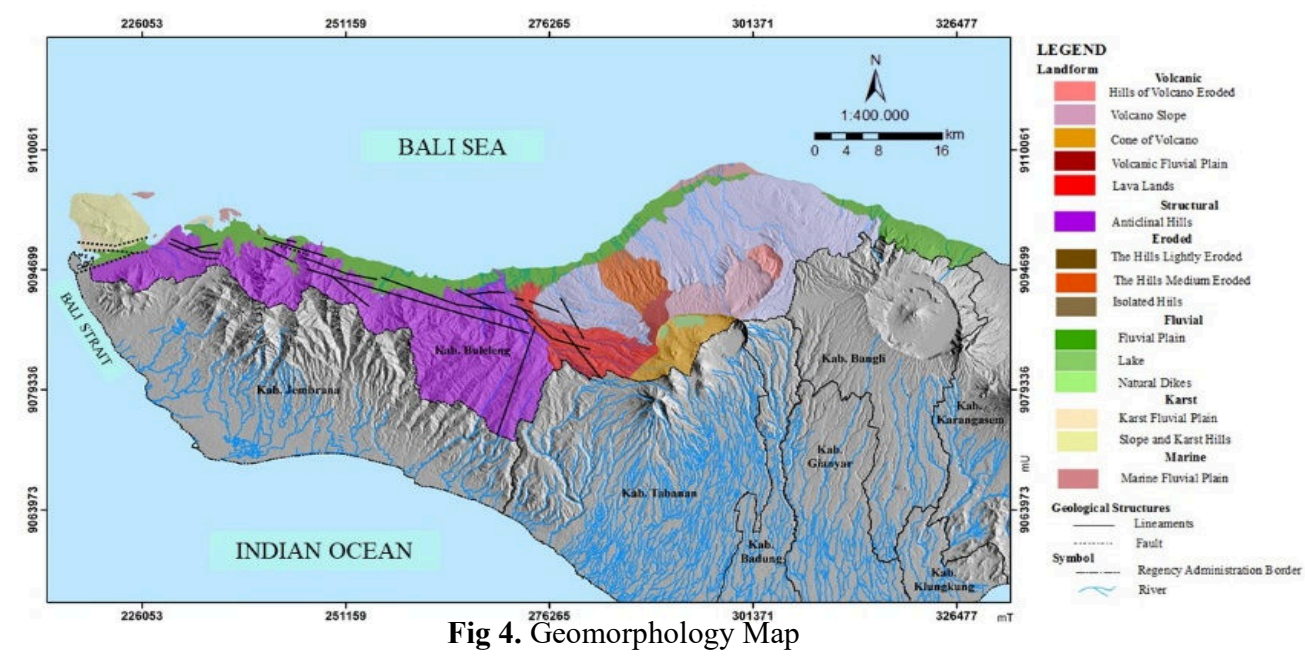

The accuracy test of the geomorphology map has been created with field conditions was $81,6 \%$. With that accuracy-test value, the interpretation landform belongs to the outstanding category [19]. The appearance of landform is distinguished by colour, as in Figure 4. The Structural landform is seen to dominated the western part of the Buleleng regency around the compact mountain with $60 \%$ transparency, so DEM can be seen as to facilitate interpretation of the structural landform visible with the rough texture shown. 


\section{Conclusion}

The conclusion that can be drawn from this research is the satellite imagery Landsat 8 , and DEM can be used in making a geomorphology map with a field accuracy test of $81,6 \%$ against six landforms in the Buleleng regency. So that geomorphology maps can be uses as a basic map in the planning and management of regional in the Buleleng regency, the role of the geomorphological map, especially in settlements development, can provide information related to the landform that is suitable and safe to build residential areas with low disaster risk. Evaluation of geomorphological maps' role will not be useful if relying solely on data from geomorphological maps only to optimize the area of the settlements. Then in this stage, planning also requires other data such as regional layout plains data. Thus, the problem that has occurred in settlement of Buleleng regency can be minimized

\section{Acknowledgement.}

We would like to thank Rector of the Ganesha University of Education, Dean of the faculty of law and social sciences, Chief of the geography department, and department staff.

\section{References}

[1] L. Pereira, B. Supriyono, and M. Mochamad, "Residential Development Planning As An Effort Improving Community Lifestyle (in Bahasa)," JISIP, vol. 4, no. 2, pp. 221$230,2015$.

[2] R. E. Missah, R. L. E. Sela, and E. D. Takumansang, "Analysis of Settlement Land Suitability Based on Regional Spatial Planning in Southeast Minahasa District (Case Study: Ratahan District) (in Bahasa)," J. Spat. Plan. Reg. City, vol. 6, no. 2, pp. 247 258, 2019.

[3] A. S. A. Nugraha, "Utilization of Multi-Level Remote Sensing Images for Mapping Drought Change (Case in East Java Province) (In Bahasa).” Universitas Gadjah Mada, 2016.

[4] M. K. Tiwari and A. Saxena, "Change Detection of Land Use/ Landcover Pattern in an Around Mandideep and Obedullaganj Area, Using Remote Sensing and GIS," IJTES, vol. 2, no. 3, pp. 342-350, 2011.

[5] G. P. D. S. Pratiwi and I. P. A. Citra, "Dynamics And Function Function Direction Of The Area In Denpasar (in Bahasa)," Geogr. Educ. Progr. Undiksha J., vol. 7, no. 1, pp. 16-23, 2019.

[6] E. A. Ayuningtyas and D. Mardiatno, "Land Suitability of Housing at Secang Watershed Kulonprogo District, Yogyakarta (in Bahasa)," Earth Indones., vol. 1, no. 2, pp. 67-74, 2012.

[7] P. Surya, "Analysis of the Hazard and Vulnerability of the Earthquake and Tsunami for Regional Planning in District of West Southwest Maluku (in Bahasa)," Indones. J. od Sci. Tech, vol. 3, no. 2, pp. 103-109, 2011.

[8] J. Rahmad, "The Parameters of Hydrology and Hydrogeology in Drainage Basin as Underlies in Spatial Planning (in Bahasa)," EMARA, vol. 1, no. 1, pp. 15-32, 2015.

[9] I. N. Ananda, F. V. Aswari, D. A. Narmaningrum, A. S. A. Nugraha, M. A. A. Asidiqi, and Y. Setiawan, "Modeling of Erosion on Jelateng Watershed Using USLE Method, Associated with an Illegal Mining Activities (PETI)," IOP Conf. Ser. Earth Environ. Sci., vol. 47, no. 1, 2016, doi: 10.1088/1755-1315/47/1/012025.

[10] E. Sutrisno, A. Sutarih, and I. Artadi, "Quality Miner Business Implications C To The Degradation Of River Quality Quality Of River (Case Study of Palasah District, 
Majalengka Regency) (in Bahasa)," Bussines Law Bonum Commune J., vol. 3, no. 1, pp. 1-10, 2020.

[11] I. Puspita, L. Ibrahim, and D. Hartono, "Influence of The Behavior of Citizens Residing in Riverbanks to The Decrease of Water Quality in The River of Karang Anyar Tarakan City (in Bahasa)," Hum. Environ. J., vol. 23, no. 2, pp. 249-258, 2016.

[12] A. . Suriadi and M. Arsjad, "Geospatial Information of Lanslide Prone Areas as Input of Spatial Planning (in Bahasa)," Globe, vol. 14, no. 1, pp. 37-45, 2012.

[13] S. Situmorang and I. G. A. Wesnawa, "Settlement Growth in Buleleng Subdistrict (in Bahasa)," JJPG, vol. 6, no. 1, pp. 21-32, 2018.

[14] G. P. B. Garcia and C. H. Grohmann, "DEM-based Geomorphological Mapping and Landforms Characterization of a Tropical Karst Environment in Southeastern Brazil," South Am. Earth Sci., vol. 93, pp. 14-22, 2019.

[15] P. Suharsono, Identification of Land Forms and Interpretation of Imagery for Geomorphology (Collection of Lecture Materials) (In Bahasa). Yogyakarta, 1988.

[16] R. F. Malik, "The Detailed Geomorphology mapping Using The Step-Wise-Grid Technique in Bompon Watershed, magelang Regency, Central Java (in Bahasa)," Earth Indones. J., vol. 6, no. 2, 2017.

[17] S. A. Aliyan, A. S. Bahri, A. Widodo, and W. Utama, "Remote Sensing Data Integration of Landsat 8 and SRTM for Geomorphological Characteristics Identification in Karst Pringkuku, Pacitan, East Java (in Bahasa)," Int. J. Adv. Sci. Eng. Inf. Technol., vol. 9, no. 1, pp. 212-218, 2019.

[18] K. Pareta and U. Pareta, "Geomorphological Interpretation Through Satellite Imageri \& DEM Data," Am. J. Geophys. Geochemistry Geosystems, vol. 1, no. 2, pp. 19-36, 2015.

[19] N. W. W. M. A and R. H. Jatmiko, “Application Of Remote Sensing Image Landsat 8 To Estimate Distribution Of Surface Coal In Some Malinau District North Borneo (in Bahasa)," Earth J., vol. 4, no. 1, 2015. 